\title{
ORYGINALNE I ZWYCZAJNE PAMIAৃTKI Z ŁODZI SPOSOBEM NA ZACHOWANIE WSPOMNIEŃ Z PODRÓŻY
}

\begin{abstract}
Abstrakt: Pamiątki są nieodłącznym elementem podróżowania. Turyści bardzo często chcą mieć jakieś materialne wspomnienie z podróży, dlatego niemalże w każdym miejscu, w którym się pojawiają można spotkać punkty sprzedaży pamiątek. Artykuł jest próbą przedstawienia charakterystyki pamiątek sprzedawanych w Łodzi. W pracy zdefiniowano pamiątkę turystyczną oraz ukazano klasyfikacje w świetle literatury. Przedstawiono przebieg i wyniki dokonanych badań na potrzeby przedmiotu „Projekt badawczy”, w ramach którego przeprowadzono inwentaryzacje łódzkich pamiątek.
\end{abstract}

Słowa kluczowe: pamiątki z Łodzi, producenci łódzkich pamiątek, wspomnienia.

\section{UNIQUE AND ORDINARY SOUVENIRS FROM ŁÓDŹ AS A WAY TO PRESERVE MEMORIES FROM THE JOURNEY}

Abstract: Souvenirs are inherent elements of traveling. Tourists often want have to some physical reminders, and for that reason small boutiques can be found everytime sightseers are visiting the location. The main aim of this article is to specify the type of souvenirs common in Łódź. In the project we have elaborated the definition of "souvenir" and pictured the classification in the literature. Moreover, the article unveils the process and the results of the scientific research focusing on the stocktaking of the touristic mementos in the Łódź area.

Keywords: souvenirs from Lodz, manufactures of souvenirs of Łódź memories.

\section{WSTĘP}

Artykuł jest podsumowaniem pracy wykonywanej podczas przedmiotu "Projekt badawczy”, realizowanego podczas pierwszego roku uzupełniających studiów magisterskich na kierunku „turystyka i rekreacja" na Uniwersytecie Łódzkim. Projekt został opracowany w dwuosobowym zespole pod okiem dr hab. Jolanty Wojciechowskiej, prof. nadzw. UŁ. Koordynatorem całego przedmiotu była dr hab. Sylwia Kaczmarek, prof. nadzw. UŁ.

Początkowym etapem był dobór losowy grup oraz ich opiekunów i wymyślonych przez nich haseł. Następnie grupa miała za zadanie je rozszyfrować i w nawiązaniu do niego ułożyć temat pracy. Inspiracją do podjęcia tematu niniejszego artykułu było hasło „Wiaderko, konewka, łódzka woda najlepsza”. Zdanie to nawiązuje do sprzedawanych w sklepie należącym do Zakładu Wodociągów i Kanalizacji w Łodzi przedmiotów kojarzących się z wodą (konewki, ręczniki, karafki, szklanki, bidony, doniczki), na których umieszczone zostało zdanie „Łódzka woda najlepsza”. Do niedawna przedmioty te sprzedawane były również w Centrum Informacji Turystycznej przy ulicy Piotrkowskiej 87. Była to oryginalna i niepowtarzalna forma pamiątek. Niestety, sprzedaż została już wycofana z CIT-u, ale gadżety nadal można nabyć w Zakładzie Wodociągów i Kanalizacji w Łodzi (http://lodz. naszemiasto.pl/artykul/gadzety-zwik-i-mpk-lodz-tra fia-do-sprzedazy-centrum,3465133,artgal,t,id,tm.html). Przedmioty kojarzone $\mathrm{z}$ wodą, które mają promować Łódź i budować jej tożsamość w tym zakresie stały się podstawą do pogłębienia tematyki pamiątek.

\section{CO TO JEST PAMIACূTKA? - DEFINICJE, RODZAJE I KATEGORIE}

Nabywanie pamiątek podczas podróży w celu podzielenia się zarówno nimi, jak i wrażeniami doznanymi w trakcie wyjazdu z najbliższymi, było znane już w starożytności. Pierwsi podróżnicy przywozili z wypraw przeróżne przedmioty nieznane w kulturze, z której pochodziła, a które miały na celu zaświadczyć o pobycie w danym miejscu. Cytując M. Banaszkiewicz: „pamiątką stać się może wszystko, pod warunkiem, że jest namacalnym dowodem odbycia podróży 
i łączy nas z przeszłością" (http://post-turysta.pl/ artykul/pokaz-mi-pamiatka-z-wakacji-a-powiem-cikim-jestes).

Można wyróżnić dwa rodzaje kupowanych pamiątek: „będą to rzeczy dostępne dla szerokiego grona turystów oraz przedmioty unikatowe, które moga nabyć bardziej majętne osoby (do tej grupy zaliczyć można np.: obrazy, antyki). Turysta kupując pamiątkę kieruje się indywidualnymi względami estetycznymi, uogólnionym obrazem o danym miejscu oraz zasobnością portfela (BANASZKIEWICZ 2012b). Ponadto pamiątki turystyczne można zaliczyć do grupy przedmiotów, które „posiadają społeczne sensy”, zostały przez kogoś zaprojektowane oraz wyprodukowane, ale to nabywca tej pamiątki nadaje jej znaczenie oraz wartość (KRAJEWSKI 2004). Przedmioty mają dla nas różną wartość. Niektóre kupowane pamiątki umieszczone są w widocznym miejscu naszego domu, aby przypominały o radosnych chwilach $\mathrm{w}$ trakcie podróży, a czasem zostają schowane i zapomniane.

Jak twierdzi M. BANASZKIEWICZ (2012a): „Kupowanie pamiątek jest nieodłączną częścią rytuału podróżowania". Stownik języka polskiego PWN (2000) opisuje pięć znaczeń słowa "pamiątka”, z czego trzy odwołuja się do pamiątek turystycznych. Pierwsze znaczenie „to coś drobnego, co przywozimy z wycieczki lub podróży”, drugie ",to przedmiot, który przypomina nam o jakiejś osobie lub wydarzeniu i jest dla nas cenny ze względu na nie", trzecie, „jeśli dajemy komuś coś na pamiątkę, to dajemy mu to, aby o nas pamiętał". W definicjach zwrócono uwagę na takie cechy pamiątki, jak: mobilność (przywozimy z podróży), wspomnienie (zarówno osoby obdarowanej, dającej jakiś upominek, jak i wydarzeń czy miejsc).

Bardzo ważną kwestią w podróżowaniu z punktu widzenia kolekcjonowania pamiątek $\mathrm{z}$ niej są jej poszczególne etapy. M. BANASZKIEWICZ (2012b) powołując się na Boyer, dzieli wyjazd turystyczny na trzy etapy: podróż wyobrażoną, przeżytą i przedłużoną. Przedłużeniu i utrwaleniu miłych wspomnień z podróży mają służyć zakupione w miejscu wypoczynku pamiątki, które następnie eksponowane są w miejscu zamieszkania i stają się bodźcem do rozmów i wspomnień. Według M. BANASZKIEWICZ (2012b) ostatnim etapem podróży jest rozpakowanie walizek podróżnych i ustawienie $\mathrm{w}$ odpowiednim miejscu zdobyczy z podróży, czyli pamiątek.

W literaturze przedmiotu można znaleźć wiele klasyfikacji i podziałów pamiątek. Najbardziej ogólny podział przedstawia A. WIECZORKIEWICZ (2012), powołując się na Celia Lury ukazuje następującą klasyfikację pamiątek:

a) przedmioty-podróżnicy - do tej grupy zalicza przedmioty związane ściśle $\mathrm{z}$ danym miejscem, jednakże $w$ innym miejscu ich znaczenie się nie zmienia; są to: dzieła sztuki, wyroby rzemieśl- nicze, przedmioty o znaczeniu historycznym, politycznym lub religijnym;

b) przedmioty-wycieczkowicze - są to rzeczy pochodzące $\mathrm{z}$ danego miejsca, które pamiątkami w rzeczy samej nie są, np. bilety wstępu, komunikacji, pocztówki, fotografie, znaleziony kamyk albo inne przedmioty; często nie są one kupowane intencjonalnie jako pamiątka, ale stają się nią, gdy tracą swoją funkcję użytkową w danym miejscu;

c) przedmioty-turyści - to pochodzące $\mathrm{z}$ danego miejsca ubiory, programy telewizyjne, produkty spożywcze, których tożsamość wskazuje na dane miejsce; najważniejszą kwestią jest że symbolizują przebyty dystans.

Inną klasyfikację opracowała K. SOSENKO (2009), która stwierdza, że: „Wyróżnić można np. pamiątki zakupione lub znalezione (kategorię tę można rozwinąć na pamiątki zdobyte lub ukradzione, np. fragmenty ruin antycznych lub sztućce hotelowe $\mathrm{z}$ wygrawerowanym monogramem), przedmioty użytkowe lub całkiem bezużyteczne, wytwory artystyczne, kicz, marne rzemiosło, pamiątki osobiste, pamiątki uniwersalne dla wszystkich, pamiątki produkowane masowo i unikat".

Dość rozbudowaną klasyfikacja pamiątek turystycznych przedstawia K. BUCZKOWSKA (2012):

- przedmioty/elementy odgrywające konkretną rolę $\mathrm{w}$ danym społeczeństwie, a obecnie wiernie odtwarzane na potrzeby rynku turystycznego, np. biżuteria, dewocjonalia, stroje, naczynia, instrumenty muzyczne, zabawki;

- kosmopolityczne gadżety $\mathrm{z}$ nazwą miejsca (często $\mathrm{z}$ etykietką: Made in China) np. breloczki, magnesy, miniatury obiektów, maskotki, kubki, popielniczki, produkty żywnościowe;

- produkty żywnościowe, np. alkohole, herbaty, owoce, słodycze;

- produkty lokalne (przeznaczone dla ludności miejscowej), np. kosmetyki, sprzęty kuchenne, ubrania;

- przedmioty/rzeczy zbierane osobiście w miejscach pobytu, np. wszelakiego rodzaju bilety, foldery, ulotki, mapy, kamienie, piasek z plaży;

- przedmioty/rzeczy zabierane, "kradzione” w miejscach pobytu, np. fragmenty zabytków, mydełka, szampony hotelowe, podstawki na piwo;

- przedmioty nieużywane przez daną społeczność, ale wytwarzane $\mathrm{z}$ myślą o turystach, np. nożyki do listów z ozdobną rękojeścią, talerze dekorowane, torby;

- przedmioty/elementy zakupione z potrzeby lub zdobyte $\mathrm{w}$ trakcie podróży, które nieplanowane stały się pamiątką, np. czapki, mapy, obuwie, parasole; 
- pozostałe, np. autograf znanej postaci, przepisy kulinarne, prezenty od gospodarzy.

Podział pamiątek $\mathrm{z}$ zupełnie innej perspektywy przedstawiają dwie autorki - J. Wojciechowska i W. Kupis, które zwracają uwagę, że rodzaj pamiątki uwarunkowany jest otaczającym środowiskiem. Autorki podają następującą klasyfikację pamiątek turystycznych: przyrodnicze (naturalne), kulturowe (antropogeniczne) i przyrodniczo-kulturowe. Przedstawiony podział jest uzależniony od walorów turystycznych obszaru, gdzie dokonuje się zakupu pamiątek (WOJCIECHOWSKA, KUPIS 2014).

Pamiątkę turystyczną można również definiować według spojrzenia wykonawcy pamiątek oraz kupującego-turysty. W szczególności dotyczy to lokalnych producentów pamiątek, których ideą jest przekazanie wartości kulturowych specyficznych dla danego regionu oraz jest to środek promocji. W przypadku masowych wytwórców pamiątek wartości estetyczne z zachowaniem lokalnych tradycji mają mniejsze znaczenie, ponieważ ukierunkowani są na osiągnięcie jak największego zysku. Z kolei dla turysty pamiątka jest wspomnieniem minionej podróży, która jest kupowana dla siebie bądź $w$ prezencie dla innych bliskich osób (WOJCIECHOWSKA, KUPIS 2014).

W świetle przeanalizowanej literatury można stwierdzić, że pamiątki dla turysty są wspomnieniem miejsca odbytej podróży. Tezę tę potwierdzają badania realizowane przez W. Kupis w 2010 r. na potrzeby pracy magisterskiej napisanej pod kierunkiem prof. Jolanty Wojciechowskiej pt. Wykorzystanie kultury ludowej w pamiatkarstwie powiatu łowickiego. Autorka pracy magisterskiej przeprowadziła badania ankietowe $\mathrm{z}$ turystami przebywającymi na Starym Rynku w Łowiczu, a także wywiady z twórcami pamiątek oraz osobami odpowiadającymi za promocję i rozwój turystyki w regionie. Niespełna połowa badanych turystów odpowiedziała, że kupuje pamiątki, aby były wspomnieniem miejsca, które odwiedzili, dla $20 \%$ ankietowanych pamiątka z podróży jest drobiazgiem bez szczególnego znaczenia. Powyższe wskazania związane są z płcią badanych, według których kobiety charakteryzuje większy sentymentalizm, a co za tym idzie skłonność do kupowania pamiątek. Podobne wnioski przedstawia K. Buczkowska, która przeprowadziła badania wśród pracowników naukowych, dydaktycznych i administracyjnych Wydziału Turystyki i Rekreacji Akademii Wychowania Fizycznego w Poznaniu w kwietniu 2012 r. Według przeprowadzonych badań $44 \%$ badanych przywozi pamiątki z podróży, 28\% zazwyczaj kupuje pamiątki, $24 \%$ odpowiedziało, że czasami. Jeśli chodzi o cel przywożenia pamiątek to $76 \%$ odpowiedziało, że przypominają o odwiedzonych miejscach, nikt $\mathrm{z}$ badanych nie wskazał odpowiedzi „Dzięki nim można chwalić się gdzie się było” (BUCZKOWSKA 2012).
Bardzo często pamiątki kupuje się nie tylko dla siebie, ale również dla bliskich osób. Ten drobny gest wynika $\mathrm{z}$ chęci podzielenia się swoją radością $\mathrm{z}$ odbytej podróży, wspomnieniami albo jest odpowiedzią na wcześniej otrzymany prezent od tej osoby (BANASZKIEWICZ 2011). Według badań przeprowadzonych przez Buczkowską pamiątkami, którymi najczęściej kupuje się dla innych są kosmopolityczne gadżety z nazwą miejsca, następnie na równi uplasowały się produkty żywnościowe przedmioty/elementy odgrywające konkretną rolę $\mathrm{w}$ danym społeczeństwie, a obecnie wiernie odtwarzane na potrzeby rynku turystycznego (BUCZKOWSKA 2012). B. DONNERSTAG (2009) twierdzi, że pamiątki nie są autentyczne „są projektorem marzeń". Pamiątka ma na celu zatrzymanie czasu, który nie wróci. Każda rzecz pochodząca z miejsca wypoczynku może być pamiątką, np. wszelakie bilety, kamienie, ulotki, mapy, to emocjonalny stosunek do tych rzeczy nadaje im wartość, sentymentalną wartość pamiątki.

\section{METODOLOGIA I PRZEBIEG BADAŃ}

Początkowym etapem przeprowadzenia badań był wybór miejsc, w których sprzedawane są pamiątki. Autorki postanowily skupić się na punktach informacji turystycznej (IT), ponieważ tam najczęściej turyści docierają na początku swojej podróży. Wybrane zostały miejsca, którym oficjalnie nadano taką nazwę, tj. Centrum Informacji Turystycznej****, Punkt Informacji Turystycznej na Dworcu PKP Łódź-Kaliska**, Punkt Informacji Turystycznej przy Stowarzyszeniu Przyjaciół Starego Miasta oraz Punkt Informacji Turystycznej Regionalnej Organizacji Turystyki w Łodzi (ROTWŁ) Manufaktura*** (http://pl.cit.lodz.pl/po kaz/24,12,140,punkt-informacji-turystycznej-rotwl-ma nufaktura). Większość z nich jest certyfikowana, co oznacza, że posiada nadaną przez Polską Organizację Turystyki gwiazdkę/ gwiazdki, które świadczą o jakości świadczonych usług (https://www.pot.gov.pl/ dzialania/1/polski-system-informacji turystycznej/cer tyfikacja-it). Po wstępnym rozeznaniu tego, w których punktach IT można nabyć pamiątki, autorki zdecydowały, aby przeprowadzić badania również w sklepach Cepelia, znajdujących się w bliskiej odległości od punktów informacji turystycznej. Było to spowodowane tym, że tylko w dwóch placówkach IT sprzedawane są przedmioty związane $\mathrm{z}$ Łodzią. W czasie badań okazało się, że jeden ze sklepów Cepelia nie należy do sieci, ale ma prywatnego właściciela, dlatego też zrezygnowano z przeprowadzania tam inwentaryzacji. Analiza większej liczby sklepów była ograniczona ze względów na to, że w trakcie trwania 
przedmiotu „Projekt badawczy” grupa, w której pracowały autorki artykułu zmniejszyła się z pięciu do dwóch osób.

Lista miejsc, w których miała się odbyć inwentaryzacja przedstawia tab. 1. Dwa pierwsze punkty podlegają Urzędowi Miasta Łodzi, w Manufakturze znajduje się informacja, która należy do Regionalnej Organizacji Turystyki Województwa Łódzkiego, natomiast na Starym Rynku punkt IT działa przy Stowarzyszeniu Przyjaciół Starego Miasta. Na liście znalazł się również sklep Cepelia znajdujący się na terenie Manufaktury. Pamiątki sprzedawane są tylko w punktach, które w tab. 1 zostały wyróżnione pogrubioną czcionką i to $\mathrm{w}$ nich przeprowadzono badania.

Tab. 1. Inwentaryzowane obiekty, w których sprzedawane są pamiątki z Łodzi

\begin{tabular}{|c|l|l|}
\hline Lp. & \multicolumn{1}{|c|}{ Nazwa } & \multicolumn{1}{|c|}{ Adres } \\
\hline 1 & Centrum Informacji Turystycznej **** & Piotrkowska 87 \\
\hline 2 & $\begin{array}{l}\text { Punkt Informacji Turystycznej na } \\
\text { Dworcu PKP Łódź-Kaliska ** }\end{array}$ & Karolewska 55 \\
\hline 3 & $\begin{array}{l}\text { Punkt Informacji Turystycznej przy } \\
\text { Stowarzyszeniu Przyjaciół Starego } \\
\text { Miasta }\end{array}$ & Stary Rynek 1 \\
\hline 4 & $\begin{array}{l}\text { Punkt Informacji Turystycznej } \\
\text { ROTWŁ Manufaktura *** }\end{array}$ & $\begin{array}{l}\text { Rynek } \\
\text { Manufaktury }\end{array}$ \\
\hline 5 & Cepelia - Manufaktura & Ogrodowa 19a \\
\hline
\end{tabular}

Źródło: opracowanie własne na podstawie badań.

Autorki zdecydowały się na przeprowadzenie inwentaryzacji, do której użyły skonstruowanej przez siebie tabeli inwentaryzacyjnej. Zawierała ona informacje dotyczące rodzaju pamiątki, ceny jednostkowej lub przedziału cenowego, opisu, w którym zwracano uwagę na materiał, kształt i wizerunek, jaki umieszczany był na przedmiotach, ekspozycji, a także innych uwag. Następnie postawiony został problem badawczy, którym było dokonanie klasyfikacji asortymentu pamiątek w łódzkich punktach informacji turystycznej i sklepie Cepelia. W celu jego zweryfikowania postawiono sześć pytań badawczych:

1. Jaki jest asortyment pamiątek związanych z Łodzią?

2. Jak różnorodna jest oferta pamiątek?

3. Czy dostępne pamiątki kojarzą się z Łodzią?

4. Które łódzkie symbole/miejsca/obiekty są przedstawiane na pamiątkach?

5. Jakie są ceny oferowanych pamiątek w Łodzi?

6. Kto produkuje łódzkie pamiątki?

Karta inwentaryzacyjna wyglądała następująco:

\section{WYNIKI BADAŃ}

Dzięki przeprowadzonej inwentaryzacji zebrano dane, które pozwoliły na scharakteryzowanie łódzkich pamiątek, ich producentów oraz porównanie asortymentu $\mathrm{w}$ wybranych punktach. Aby tego dokonać przeanalizowano karty inwentaryzacyjne i wybrano $\mathrm{z}$ nich istotne informacje. Największy asortyment pamiątek związanych z Łodzią znajduje się w punkcie IT w Manufakturze, najmniejszy natomiast na Starym Rynku, co wynika $z$ faktu, że obok znajduje się prywatna Cepelia, w której można otrzymać przedmioty kojarzone z Łodzią. Do punktu na Starym Rynku nie dociera tak wielu turystów jak do punktu IT w Manufakturze, ale osoby, które lubią książki, albumy zdecydowanie powinny udać się na Stary Rynek, ponieważ tam ta oferta jest najbardziej urozmaicona. W sklepie Cepelia oprócz pamiątek z Łodzi można znaleźć przedmioty związane $\mathrm{z}$ całym województwem łódzkim, a także typowe dla tej firmy wyroby $z$ ceramiki $z$ Bolesławca. Bardzo ważne jest to, że w punktach IT można otrzymać bezpłatne ulotki, mapy, gazety o Łodzi i regionie.

\section{1. ŁÓDZKIE PAMIATTKI}

W tab. 2 przedstawiono rodzaje pamiątek i ich ceny w każdym z punktów, gdzie odbyła się inwentaryzacja. Oprócz wymienionych niżej przedmiotów w ofercie znalazły się również długopisy, naklejki, zapalniczki, etui na okulary, kalendarze, kieliszki, popielniczki, talerzyki ozdobne, obrazki, smyczki. Pamiątki wymienione $\mathrm{w}$ tab. 2 zostały przedstawione bardziej szczegółowo, ponieważ - jak wynika z obserwacji autorek - cieszą się największym zainteresowaniem i jest ich najwięcej. Ceny za pamiątki nie są mocno zróżnicowane $\mathrm{w}$ poszczególnych punktach sprzedaży. Zazwyczaj ten sam rodzaj, można kupić w podobnej cenie $\mathrm{w}$ każdym $\mathrm{z}$ punktów. Inny jest natomiast przedział cenowy przedmiotów tego samego asortymentu. W przypadku większych rozbieżności asortyment produktów był w sklepie bogatszy. Jak można zauważyć w kolumnie z pamiątkami sprzedawanymi w IT na Startym Rynku brakuje rzeczy, które można nabyć $\mathrm{w}$ innych punktach. Potwierdza to wcześniejszą informację o tym, że oferta jest tam najbardziej uboga. We wspomnianym punkcie sprzedawany jest tylko jeden rodzaj magnesów, stąd jednostkowa cena za ten przedmiot. Najtańsze są pocztówki, zakładki, a także

\begin{tabular}{|c|c|c|c|c|c|}
\hline Lp. & Rodzaj pamiątki & Cena jednostkowa/przedział cenowy & Opis & Ekspozycja & Uwagi \\
\hline & & & Kształt & & \\
& & & Materiał & & \\
& & & Wizerunek & & \\
\hline
\end{tabular}


naklejki i opaski na rękę. Za dosyć niską cenę można kupić także niektóre magnesy i breloki. Najdroższe są książki i albumy o Łodzi, a także największy rozmiar figurki z wizerunkiem Tuwima na ławeczce.

Tab. 2. Rodzaj pamiątki a cena w badanych punktach sprzedaży w Łodzi

\begin{tabular}{|c|c|c|c|}
\hline \multirow[t]{2}{*}{ Pamiątki } & $\begin{array}{c}\text { Punkt IT } \\
\text { w Manufakturze }\end{array}$ & Cepelia & $\begin{array}{c}\text { Punkt IT } \\
\text { na Starym } \\
\text { Rynku }\end{array}$ \\
\hline & \multicolumn{3}{|c|}{ Cena w zł (jednostkowa/ przedział cenowy) } \\
\hline Magnesy & $5-20$ & $5-27$ & 6 \\
\hline Pocztówki & $1-3$ & 1 & 1,50 \\
\hline Kubki & 20 & 22 & 18 \\
\hline Breloki & $7-12$ & $7-12$ & $\mathrm{x}$ \\
\hline Figurki & $10-55$ & $5-15$ & $25-55$ \\
\hline Naparstki & $10-14$ & $10-13$ & $x$ \\
\hline Zakładki & 8 & 8 & 8 \\
\hline $\begin{array}{l}\text { Książki, albumy, } \\
\text { przewodniki, } \\
\text { mapy }\end{array}$ & $4,50-85$ & $\mathrm{x}$ & $13-80$ \\
\hline Rajstopy & 25 & $x$ & $x$ \\
\hline
\end{tabular}

Źródło: opracowanie własne na podstawie badań.

Na uwagę zasługuje fakt, że najbardziej oryginalną pamiątką (według autorek) okazały się rajstopy. Sprzedawane są one jedynie w punkcie IT w Manufakturze. Produkuje je łódzka firma Gabriella (fot. 1). Swoją wyjątkowość zawdzięczają wzorom, które się na nich znajdują. Dostępne są rajstopy w fabryczki, rajstopy z pismem Władysława Strzemińskiego, czy też zakończone w połowie uda główną bramą Manufaktury. Niewątpliwie jest to produkt dla osób odważnych, które lubią wyróżniać się. Rajstopy mogą być zarówno pamiątką przywiezioną z podróży, jak również elementem garderoby łodzianki, która kocha swoje miasto.

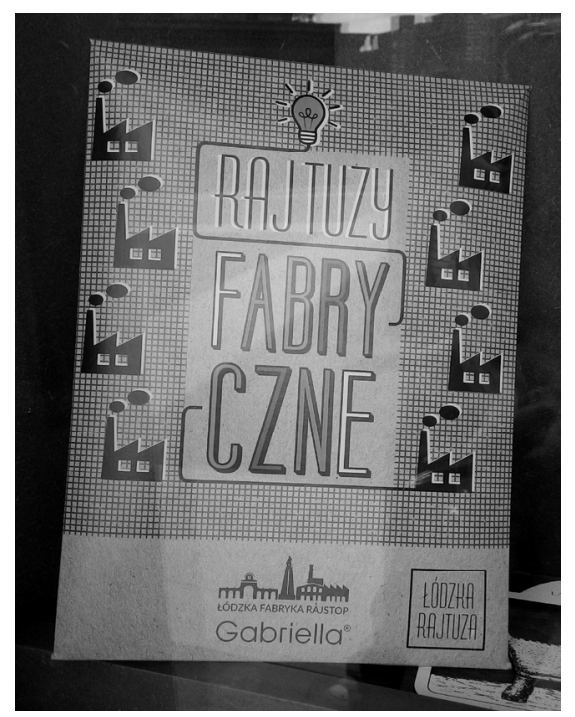

Fot. 1. Opakowanie rajtuz produkowanych w Łodzi z wzorami utożsamianymi z miastem Fot. M. Zwolińska

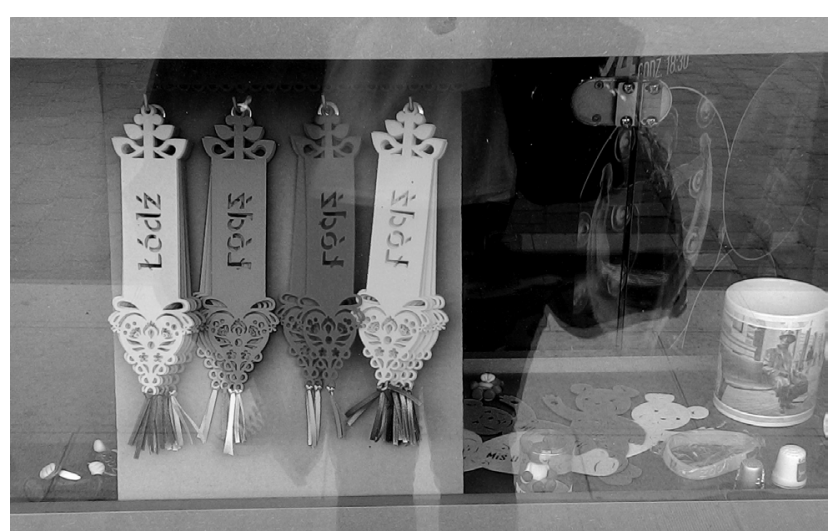

Fot. 2. Gablota z pamiątkami z Łodzi Fot. M. Zwolińska

Tab. 3. Charakterystyka łódzkich pamiątek

\begin{tabular}{|c|c|c|}
\hline $\begin{array}{l}\text { Rodzaj } \\
\text { pamiątki }\end{array}$ & Materiał & Wizerunki \\
\hline Magnesy & $\begin{array}{l}\text { Drewno, } \\
\text { ceramika, } \\
\text { modelina, } \\
\text { plastik, } \\
\text { metal, }\end{array}$ & $\begin{array}{l}\text { Plac Wolności, Pałac Poznańskiego, } \\
\text { Manufaktura, Miś Uszatek, ulica } \\
\text { Piotrkowska, ławeczka Tuwima, } \\
\text { klatka filmowa, maszyna do szycia, } \\
\text { łódź podwodna, łódka - herb Łodzi, } \\
\text { godło Polski, Żyd z grosikiem }\end{array}$ \\
\hline Pocztówki & Papier & $\begin{array}{l}\text { Pomniki fabrykantów, postaci z ba- } \\
\text { jek (SE-MA-FOR), fabryki i ich } \\
\text { wnętrza, ulica Piotrkowska, Manu- } \\
\text { faktura, Pałac Poznańskiego, plac } \\
\text { Wolności, katedra }\end{array}$ \\
\hline Kubki & Ceramika & $\begin{array}{l}\text { Plac Wolności, Manufaktura, } \\
\text { ławeczka Tuwima, ulica Piotr- } \\
\text { kowska, fabryki, Pałac Poznań- } \\
\text { skiego, napis „Łódź” }\end{array}$ \\
\hline Breloki & $\begin{array}{l}\text { Guma, } \\
\text { plastik, } \\
\text { szkoło, } \\
\text { modelina }\end{array}$ & $\begin{array}{l}\text { Plac Wolności, Pałac Poznańskiego, } \\
\text { Miś Uszatek, herb Łodzi, napis } \\
\text { „Łódź”, Manufaktura, ławeczka } \\
\text { Tuwima }\end{array}$ \\
\hline Figurki & $\begin{array}{l}\text { Modelina, } \\
\text { ceramika }\end{array}$ & $\begin{array}{l}\text { Ławeczka Tuwima, Miś Uszatek, } \\
\text { Żyd z grosikiem, napis „Łódź” }\end{array}$ \\
\hline Naparstki & $\begin{array}{l}\text { Ceramika, } \\
\text { metal }\end{array}$ & Plac Wolności, herb Łodzi, łódka \\
\hline Zakładki & Filc & $\begin{array}{l}\text { Napis „Łódź”, Miś Uszatek, plac } \\
\text { Wolności }\end{array}$ \\
\hline
\end{tabular}

Źródło: opracowanie własne na podstawie badań.

Kolejna analiza dotyczyła materiałów, z jakich wytworzone zostały pamiątki oraz wizerunków, jakie są na nich przedstawiane. Niewątpliwie największa różnorodność pod względem obu kryteriów występuje wśród magnesów. Ciekawym pomysłem są różnokolorowe filcowe zakładki do książek z napisem „Łódź" oraz w kształcie Misia Uszatka (fot. 2). Jeśli chodzi o wizerunki, to $\mathrm{w}$ każdym rodzaju są to miejsca charakterystyczne $\mathrm{i}$ znane $\mathrm{w}$ Łodzi. Nie ma pa- 
miątek szokujących, na których przedstawiono miejsca mniej znane, ale równie ważne. Miejsca, obiekty przedstawiane rzadko lub prawie w ogóle, a tak samo istotne dla Łodzi to: Bazylika Archikatedralna św. Stanisława, Księży Młyn, Park Źródliska, stacja Radegast (tab. 3, fot. 3).

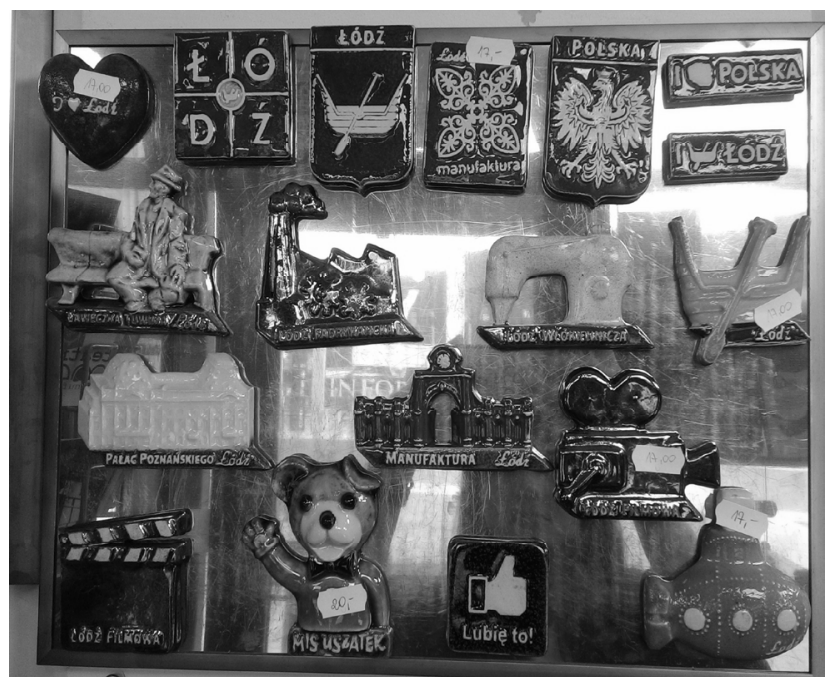

Fot. 3. Tablica magnetyczna z magnesami zawierającymi "tódzkie" pamiątki Fot. M. Zwolińska

Jeśli chodzi o ekspozycję to trzeba stwierdzić, że pamiątki nie są prezentowane $\mathrm{w}$ nadzwyczajny sposób. Magnesy zazwyczaj przyczepione są do tablic magnetycznych, przedmioty, które można postawić stoją na półkach lub biurkach sprzedawców. Ponadto w punkcie IT w Manufakturze oraz sklepie Cepelia, przedmioty wystawione są w szklanych gablotach widocznych z zewnątrz.

Na podstawie wyników badań oraz dostępnej literatury autorki zaproponowały podział łódzkich pamiątek na oryginalne i zwyczajne. W oparciu o klasyfikacje K. BUCZKOWSKIEJ (2012), wśród oryginalnych rozróżniły produkty lokalne oraz produkty wytwarzane $\mathrm{z}$ myślą o turystach, natomiast zwyczajne podzieliły na kosmopolityczne przedmioty $\mathrm{z}$ nazwą miejscowości oraz kupowane $\mathrm{w}$ potrzebie $\mathrm{w}$ trakcie podróży (rys. 1).

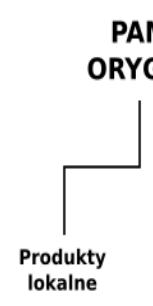

PAMIATKI ORYGINALNE

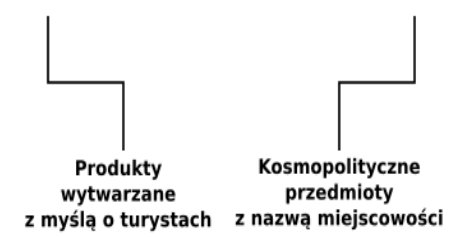

Rys. 1. Podział łódzkich pamiątek

Źródło: opracowanie własne na podstawie klasyfikacji K. BUCZKOWSKIEJ (2012)
Do produktów lokalnych, czyli przeznaczonych dla ludności miejscowej (BUCZKOWSKA 2012), zaliczone zostały "łódzkie" rajstopy. Wśród pamiątek wytwarzanych $\mathrm{z}$ myślą o turystach są magnesy o oryginalnych kształtach, filcowe zakładki do książek, ławeczka Tuwima (figurka), etui na okulary. Jeśli chodzi o rzeczy zwyczajne, jako kosmopolityczne przedmioty, uznano m.in. breloki, naparstki, niewyróżniające się magnesy, kubki, talerzyki ozdobne, długopisy, figurki $\mathrm{z}$ modeliny. Produkty kupowane $\mathrm{z}$ potrzeby w trakcie podróży to mapy oraz przewodniki.

\subsection{PRODUCENCI ŁÓDZKICH PAMIĄTEK}

Podczas przeprowadzania inwentaryzacji udało się również znaleźć niektórych producentów łódzkich pamiątek. Istotne znacznie ma fakt, że większość $\mathrm{z}$ nich ma swoje siedziby $\mathrm{w}$ Łodzi, więc w dużej mierze są to produkty tworzone na miejscu. Jest to ważne i wiąże się $z$ tematem autentyczności pamiątek, poruszanym m.in. przez A. WIECZORKIEWICZ (2010). Kupując pamiątki turyści bardzo często zwracają uwagę na ich autentyczność, oczekują rzeczy dobrej jakościowo, najlepiej wykonanej przez lokalnych producentów. Jednakże nie jest to jednolite stanowisko, ponieważ dla części odwiedzających jakiś obszar cena pamiątki będzie najbardziej istotna, a więc prawdopodobnie zakupią tańsze przedmioty, które często pochodzą z Chin, mają jedynie napis danej miejscowości i to będzie dla nich satysfakcjonujące. Takie produkty również pojawiają się $\mathrm{w}$ lódzkich sklepach. Jedna z firm produkuje takie same pamiątki dla różnych miast, zmienia się na nich tylko nazwa miejscowości.

Tab. 4. Producenci łódzkich pamiątek

\begin{tabular}{|l|l|l|l|}
\hline $\begin{array}{c}\text { Nazwa } \\
\text { producenta, } \\
\text { wytwórcy }\end{array}$ & $\begin{array}{l}\text { Siedziba } \\
\text { producenta }\end{array}$ & \multicolumn{1}{|c|}{ Asortyment } & \multicolumn{1}{|c|}{$\begin{array}{c}\text { Strona } \\
\text { internetowa } \\
\text { www }\end{array}$} \\
\hline Robot & Eódź & $\begin{array}{l}\text { Magnesy } \\
\text { ceramiczne }\end{array}$ & - \\
\hline $\begin{array}{l}\text { Model - } \\
\text { Man }\end{array}$ & Eódź & $\begin{array}{l}\text { Magnesy, figurki } \\
\text { z modeliny, } \\
\text { zakładki filcowe }\end{array}$ & - \\
\hline Bady & Kobyłka & $\begin{array}{l}\text { Magnesy, breloki, } \\
\text { dzwonki, naparstki }\end{array}$ & $\begin{array}{l}\text { www. } \\
\text { bady. pl }\end{array}$ \\
\hline Liwi & Bełchatów & Eaweczka Tuwima & - \\
\hline Gabriella & Eódź & Rajstopy & $\begin{array}{l}\text { www. } \\
\text { gabriella. pl }\end{array}$ \\
\hline Itaka & Eódź & $\begin{array}{l}\text { Książki (É́dź Szkice } \\
\text { do portretu miasta) }\end{array}$ & - \\
\hline Compas & Kraków & Mapy & $\begin{array}{l}\text { www. } \\
\text { compass. } \\
\text { krakow.pl }\end{array}$ \\
\hline
\end{tabular}

Źródło: opracowanie własne na podstawie badań. 
Firma Bady zajmuje się dystrybucją pamiątek związanych z Polską, ale też z poszczególnymi miastami kraju, ponadto ma licencje na tworzenie pamiątek $\mathrm{z}$ logo Solidarność. W ofercie znajdują się: breloki, długopisy, kule śniegowe, magnesy, naklejki, naszywki, otwieracze, zapalniczki, ceramika, dzwonki, koszulki, łyżeczki, monety, naparstki, opakowania, przypinki, szkło. Po przeanalizowaniu oferty pamiątek dla poszczególnych miast można stwierdzić, że nie jest ona oryginalna. Częstą praktyką jest powielanie wizerunku zabytków różnych miast na tych samych przedmiotach (http:/ / www.bady.pl).

Wytwórcą słynnej ławeczki Tuwima jest firma Liwii, jest to pracownia ceramiczna Lidii i Witolda Kopytkiewiczów. Współpracuje z rzeźbiarzem Wojciechem Gryniewiczem. Pamiątka jest miniaturą pomnika znanego jako Ławeczka Tuwima (https://liwi ceramika.wordpress.com).

Ciekawą i niestandardową pamiątką z Łodzi mogą być wspomniane już wcześniej rajstopy, produkowane przez firmę Gabriella. Na stronie internetowej Gabrielli możemy przeczytać: „Łódzka Rajtuza jest wyrazem miłości do Łodzi, jej włókienniczej historii i kobiet, które ją wytworzyły". Przemysł pończoszniczy jest charakterystyczny dla Łodzi, a "pamiątka” jak najbardziej kojarzy się z tym miastem, ponadto jest bardzo oryginalna. Warto dodać, że lódzka firma produkuje również Rajtuzy Stołeczne dla Warszawianek i turystek zwiedzających stolicę (https:// www. gabriella.pl/pl/produkt/rajtuzy-z-miasta-lodzi. html).

W punktach z pamiątkami dostępne są również mapy wydawnictwa Compass: Łódź - plan miasta, Łódzkie - część pótnocna, Łódzkie - część pótnocna + część południowa, Łódzkie - część południowa, Okolice Łodzi na rowerze, Park Krajobrazowy Wzniesień Łódzkich, Ziemia sieradzka (http://www.compass.krakow.pl).

\section{PROJEKT PAMIĄTKI}

Autorki postanowiły także stworzyć swój własny pomysł na pamiątkę. Obserwując ludzi na ulicy można zauważyć, że dużo z nich nosi ze sobą płócienne torby. Propozycją jest zatem torba w kształcie łódki z napisem "Spotkajmy się w Łodzi" - nawiązującym do pamiątki ławeczki Tuwima, na której umieszczone jest to samo hasło, jak również z napisami „Łódź to najlepsze miasto”, "Przyjedź do Łodzi i zobacz o co tutaj chodzi". Torby byłyby sprzedawane w trzech kolorach: czerwony, żółty i beżowy.

Drugim pomysłem jest pocztówka w kształcie łódki, na której przedstawione będą zarówno miejsca charakterystyczne dla Łodzi, jak i mniej znane. Na każdym obrazku będzie podpis tego co przed- stawia. Ponadto na odwrocie znajdować się będzie uproszczona mapka, z umieszczonymi obiektami. Ułatwi to turystom dotarcie do tych miejsc.

\section{WNIOSKI}

Z przedstawionej analizy wynika, że oferta pamiątek związanych $\mathrm{z}$ Łodzią jest bardzo różnorodna, dostosowana do potrzeb turystów w różnym wieku i o różnych wymaganiach. Jest wiele rodzajów przedmiotów. Wizerunki na nich przedstawiane oraz ich kształt kojarzą się z Łodzią. Pojawiają się pamiątki oryginalne, produkowane przez lokalnych producentów - za wyższą cenę, jak również produkowane masowo, które można kupić za niewielką kwotę. Autorkom wydaje się jednak, że producenci powinni cały czas tworzyć niepowtarzalne przedmioty, które będą związane $\mathrm{z}$ Łodzią i jej historią.

Największy wybór pamiątek oferuje punkt Informacji Turystycznej w Manufakturze. Punkty związane z Urzędem Miasta nie prowadzą sprzedaży w ogóle, co może świadczyć o tym, że nie było tam dużego zainteresowania pamiątkami. Oprócz przedmiotów, które można kupić w punktach istnieje możliwość pobrania bezpłatnych materiałów pomocnych podczas zwiedzania Łodzi.

Temat nie został wyczerpany, ponieważ w Łodzi istnieje kilka innych sklepów z pamiątkami, których autorki nie wzięły pod uwage w swoich badaniach, m.in. sklep w Centrum Turysty Księży Młyn, Tytka na Pietrynie. Co więcej, autorki nie znalazły opracowania, w którym przeprowadzone zostały analogiczne badania, dlatego warto zastanowić się, czy nie wykonać ich również w innych miastach.

\section{BIBLIOGRAFIA}

BANASZKIEWICZ M., 2011, Pamiątki turystyczne - w poszukiwaniu tożsamości, ,Turystyka Kulturowa”, 4, www.turystykakultu rowa.org, s. 4-16.

BANASZKIEWICZ M., 2012a, Dialog międzykulturowy. Przypadek polsko-rosyjski, Wyd. Uniwersytetu Jagiellońskiego, Kraków.

BANASZKIEWICZ M., 2012b, Pamiatki turystyczne - miniatura czy karykatura dziedzictwa narodowego?, "Studia Etnologiczne i Antropologiczne", 12, s. 167-178.

BUCZKOWSKA K., 2012, Jakość podróży zatrzymana w pamiątkach, [w:] M. Kazimierczak (red.), Jakość życia w kulturowych przestrzeniach podróżowania, Wyd. AWF im. E. Piaseckiego, Poznań, s. 78-95.

DOnNerstag B., 2009, Zatrzymać czas. Przedmiot pamiątka wspomnienie, Wyd. Muzeum Historii Katowic, Katowice.

KRAJEWSKI M., 2004, W stronę socjologii przedmiotów, [w:] M. Golka (red.), W cywilizacji konsumpcyjnej, Poznań, s. 43-64.

Stownik języka polskiego PWN, 2000, Wydawnictwo Naukowe PWN, Warszawa. 
SOSENKO K., 2009, Kobieta w podróży, [w:] P. Krasny, D. Ziarkowski (red.), Sztuka i podróżowanie. Studia teoretyczne $i$ historyczno-artystyczne, Proksenia, Kraków, s. 263-264.

WIECZORKIEWICZ A., 2012, Apetyt turysty. O doświadczaniu świata w podróży, Wyd. Univeritas, Kraków.

WOJCIECHOWSKA J., KUPIS W., 2014, Pamiątki turystyczne regionu towickiego inspirowane kulturq ludowa, „Folia Turistica”, 31, s. $105-125$.

http:/ /lodz.naszemiasto.pl/artykul/gadzety-zwik-i-mpk-lodztrafia-do-sprzedazy-w-centrum,3465133,artgal,t,id,tm.html; 4.06.2017. http://pl.cit.lodz.pl/pokaz/24,12,140,punkt-informacji-turysty cznej-rotwl-manufaktura; 21.05.2017.

http:/ / post-turysta.pl/artykul/pokaz-mi-pamiatka-z-wakacji-apowiem-ci-kim-jestes; 19.09.2017.

http:/ / www.bady.pl/zamow/\#/\%C5\%81\%C3\%B3d\%C5\%BA $\mathrm{n}, \mathrm{f} ;$, 20.05.2017.

https:/ / www.gabriella.pl/pl/produkt/rajtuzy-z-miasta-lodzi. html; 21.05.2017.

https://www.pot.gov.pl/dzialania/1/polski-system-informacjiturystycznej/certyfikacja-it; 17.09.2017.

Artykuł wpłyną:

22 sierpnia 2017

Zaakceptowano do druku:

8 listopada 2017 